\title{
Synchronous Breast and Abdominal Fibromatosis: A Rare Case
}

\author{
Senkron Meme ve Abdominal Fibromatozis: Nadir Bir Olgu Sunumu
}

\section{Ömer Karahan', Meryem İlkay Eren Karanis² ${ }^{2}$ Hande Köksal'}

\footnotetext{
${ }^{1}$ Sağlık Bilimleri University, Konya Education and Research Hospital, Department of General Surgery, Konya, Turkey
}

${ }^{2}$ Sağlık Bilimleri University, Konya Education and Research Hospital, Department of Pathology, Konya, Turkey

\section{ABSTRACT}

Fibromatosis, also known as desmoid tumor, is a rare disease. Breast fibromatosis is extremely rare. Herein, we present a case of breast and abdominal aggressive fibromatosis in a woman to discuss optimal treatment management.

Key Words: Aggressive fibromatosis, breast, intraabdominal

\section{ÖZET}

Fibromatozis; diğer adıyla desmoid tümor; nadir görülmektedir. Memede ise daha da az rastlanır. Burada memede ve karın içinde senkron olarak saptanan agresif fibromatozis uygun tedavi yaklaşımlarının tartışılması amacıyla sunulmuştur.

Anahtar Sözcükler: Agresif fibromatozis, meme, karıniçi

Geliş Tarihi: 03.12 .2016

Kabul Tarihi: 11.04.2017

\section{INTRODUCTION}

Fibromatosis, also known as desmoid tumor, is a rare disease. Breast fibromatosis is extremely rare and represents $4 \%$ of extra-abdominal desmoid tumors and $0,2 \%$ of all breast tumors. Aggressive fibromatosis (AF) arises from fibroblasts and it can be located at any part of the body. Although it is benign, it is locally aggressive. The cause of the AF is uncertain and can be related to trauma, hormonal factors or genetic association (1). The AF of the breast generally occurs in implant-associated breast or a history of trauma (often surgical) (2-8). Herein, we present a case of breast and abdominal $\mathrm{AF}$ in a woman to discuss optimal treatment management.

\section{CASE REPORT}

A 32-year-old woman presented with a palpable mass on right breast with a history of two weeks. On physical examination there was a painless, soft, palpable lesion, $2 \mathrm{~cm}$ in diameter with unclear borders. Ultrasonography revealed an irregular shaped, hypoechoic mass of size $18 \times 15 \mathrm{~mm}$ at 1 o'clock direction of right breast, $10 \mathrm{~cm}$ away from the nipple. The lesion was categorized as BIRADS 5 and tru-cut biopsy was performed. Histopathological examination indicated a possibility of a low grade mesenchymal tumor (Fig 1).

Address for Correspondence / Yazışma Adresi: Hande Koksal, MD Saglik Bilimleri University, Konya Education and Research Hospital, Department of General Surgery, Konya, Turkey E-mail: drhandeniz@yahoo.com

(CTelif Hakkı 2017 Gazi Üniversitesi Tıp Fakültesi - Makale metnine http://medicaljournal.gazi.edu.tr/ web adresinden ulaşılabilir. CCopyright 2017 by Gazi University Medical Faculty - Available on-line at web site http://medicaljournal.gazi.edu.tr/

doi:http://dx.doi.org/10.12996/gmj.2017.62 
During staging work-up thorax tomography noted the involvement of pectoralis muscle and abdominal tomography revealed a similar-looking another lesion located on abdominal wall, right paraumblical region and trucut biopsy was the same as breast pathology (Fig 2). Therefore the patient underwent wide local excision for both breast and abdominal wall and cavity. The breast lesion was excised with tumor free margins. Also, thin layer of pectoralis muscle was excised with the breast specimen. Macroscopically the tumor was $1.8 \mathrm{~cm}$ in diameter and immunhistochemically SMA, Vimentin, and Desmin were positive, and CD34, AE1/AE3 were negative.

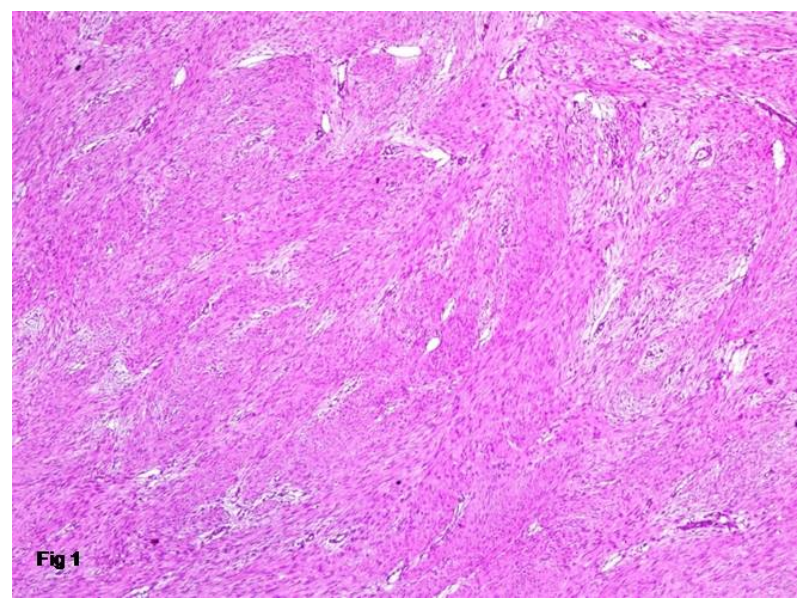

Figure 1: Fibromatosis: Tumoral lesion composed of long sweeping fascicles. HEx50, Breast.

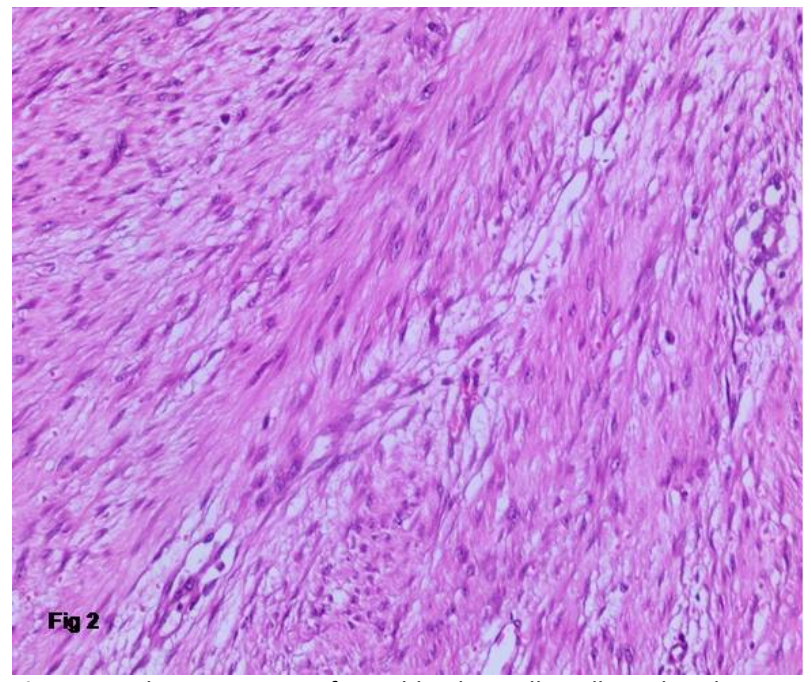

Figure 2: Fibromatosis: Uniform, bland spindle cells with pale, eosinophilic cytoplasm, poorly defined cell borders, oval to elongated nuclei.HEx200, Breast.

During abdominal surgery small intestine was explorated to be involved in tumor from 120th $\mathrm{cm}$ of Treitz ligament. So, $70 \mathrm{~cm}$ small intestine was resected with tumor. The final histopathological findings were consistent with fibromatosis. The patient is under follow-up for 54 months without any treatment.

\section{DISCUSSION}

Aggressive fibromatosis is a rare fibroblastic proliferation arising in musculoaponeurotic structure. In women, most commonly occur after childbirth. The prevalence of AF is higher in patients with Gardner syndrome and familial adenomatous polyposis. Although histologically benign, desmoids are often locally invasive and associated with a high local recurrence rate after resection (1).

Aggressive fibromatosis can be seen at any body site but especially trunk/extremity, abdominal wall and intraabdominal (bowel and mesentery). In patients with familial adenomatous polyposis, intraabdominal desmoids predominate. Extra-abdominal AFs are generally located scapular girdle, abdominal wall, extremities, pelvic girdle, chest wall, trunk, head and neck region. Breast involvement is rare and its prevalence is $4 \%$ in the patients with extra-abdominal (10). The etiology of the breast involvement is uncertain. However, the patients with breast AF have the histories of breast cancer or breast surgery and familial adenomatous polyposis (2). The major presenting symptom is a palpable mass.

In our patient, the presenting symptom was breast mass. Ultrasound revealed irregular shaped hypoechoic mass with ill-defined borders which attached to the pectoralis muscle sonographically.

In the treatment of the AFs, if the patients have asymptomatic and stable disease, observation is suggested. The other patients are treated. The treatment choices are surgery (if possible, with negative margins), radiotherapy or systemic therapy.

In conclusion, breast AF is extremely rare, also to our knowledge this is the first case reported with concomitantly breast and abdominal AF in a woman. Although it is a benign entity pathologically, it can grow aggressively. More over this unusual lesion can display atypical radiologic features and mimic carcinomas. Optimal management of fibromatosis is radical surgical excision. Chemotherapy, radiotherapy and hormonal therapy have also been suggested.

\section{Conflict of interest}

No conflict of interest was declared by the authors.

\section{REFERENCES}

1. Mendenhall WM, Zlotecki RA, Morris CG, Hochwald SN, Scarborough MT. Aggressive fibromatosis. Am J Clin Oncol. 2005; 28:211-5.

2. Neuman HB, Brogi E, Ebrahim A, Brennan MF, Van Zee KJ. Desmoid tumors (fibromatoses) of the breast: a 25-year experience. Ann Surg Oncol. 2008;15:274-80.

3. Brogi E. Benign and malignant spindle cell lesions of the breast. Semin Diagn Pathol. 2004; 21: 57-64.

4. Dale PS, Wardlaw JC, Wootton DG, Resnick JI, Giuliano AE. Desmoid tumor occurring after reconstruction mammaplasty for breast carcinoma. Ann Plast Surg. 1995; 35: 515-8.

5. Godwin Y, McCulloch TA, Sully L. Extra-abdominal desmoid tumour of the breast: review of the primary management and the implications for breast reconstruction. Br J Plast Surg. 2001; 54:268-71.

6. Erguvan-Dogan B, Dempsey PJ, Ayyar G, Gilcrease MZ. Primary desmoid tumor (extraabdominal fibromatosis) of the breast. AJR Am J Roentgenol. 2005; 185: 488-9.

7. Catalano F, Furci M, Fancello R, Costanzo M. Giant recurrent fibromatosis of the breast: a case report. Clinical features and implications for treatment. Chir Ital. 2006; 58: 538-43.

8. Muller M. Muller M, Dessogne $P$, et al. Desmoid tumor of the breast in a 9 years old little girl. Ann Pathol. 2011; 31: 41-5.

9. Gergelé F, Guy F, Collin F, Krausé D. A desmoid tumour associated with a breast prosthesis. Diagn Interv Imaging. 2012; 93: e200-3.

10. Gronchi A, Casali PG, Mariani L, et al. Quality of surgery and outcome in extra-abdominal aggressive fibromatosis: a series of patients surgically treated at a single institution. J Clin Oncol. 2003; 21: 1390-7. 